\title{
New European Union's Requirements and IFRS Practice Statement “Management Commentary”: Does MD\&A Disclosure Quality Affect Analysts’ Forecasts?
}

\author{
S. Pisano, F. Alvino \\ Parthenope University, Naples, Italy
}

\begin{abstract}
The Management Discussion and Analysis (MD\&A) is a mandatory document under the European Union's (EU) law. In 2003, the EU issued Directive 2003/51/EC, which broadened the information that firms have to provide in their MD\&A, and in 2010 the International Accounting Standards Board (IASB) issued the International Financial Reporting Standards (IFRS) Practice Statement "Management Commentary”, a non-binding guidance for the presentation of this document. The aim of this paper is to examine the relationship between MD\&A disclosure quality and properties of analysts' forecasts. In fact, although most studies found that financial analysts mainly refer to financial statement data in forecasting earnings, there are few researches highlighting the importance of MD\&A disclosures for financial analysts. On this basis, Ramnath, Rock, and Shane (2008) called for researches in order to better understand the relationship between the information really used by analysts and their forecasts. To assess the quality of MD\&A disclosures, we developed a multidimensional measure on the basis of the EU requirements and the IFRS Practice Statement, and then we regressed this variable on both forecast accuracy and dispersion. The findings show that our measure of MD\&A disclosure quality is significantly and positively related to forecast accuracy. We conducted other analyses in order to better understand the previous relationship and we found that, if we analyze the different information contained in the MD\&A statement, financial analysts consider useful accounting and financial data in forecasting earnings. These results enhance our understanding of the role of MD\&A disclosures in the wide set of information that firms provide to financial statement users.
\end{abstract}

Keywords: Management Discussion and Analysis (MD\&A), Directive 2003/51/EC, International Financial Reporting Standards (IFRS) Practice Statement “Management Commentary”, disclosure quality, analysts’ forecasts

\section{Introduction}

In recent years, the relevance and importance of narrative disclosures have been widely recognized (Beattie, McInnes, \& Fearnley, 2004). Both regulators and professional standards setters are focusing their attention on Management Discussion and Analysis (MD\&A) statement in annual reports (Clarkson, Kao, \& Richardson, 1999) by issuing documents that emphasize the role and importance of narrative statement disclosures (American Institute of Certified Public Accountants [AICPA], 1994; Accounting Standards Board [ASB], 2006; Financial Accounting Standards Board [FASB], 2001; Canadian Institute of Chartered Accountants [CICA], 2009).

S. Pisano, Ph.D., assistant professor, Department of Law, Parthenope University.

F. Alvino, Ph.D., full professor, Department of Law, Parthenope University.

Correspondence concerning this article should be addressed to S. Pisano, Department of Law, Parthenope University, Via Generale Parisi, n. 13, 80132, Napoli, Italy. Email: sabrina.pisano@uniparthenope.it. 
In Europe, the MD\&A statement is a mandatory document according to Art. 46 of the Fourth Council Directive 78/660/EEC. In 2003, the EU issued the Accounts Modernisation Directive 2003/51/EC, which broadened the content of Art. 46, requiring firms to provide more information in their MD\&A.

The relevance of the MD\&A statement has been recognized also by the International Accounting Standards Board (IASB), which issued the International Financial Reporting Standards (IFRS) Practice Statement “Management Commentary” in December 2010.

This paper aims at analyzing the role played by the MD\&A disclosures in the activity of forecasting earnings by financial analysts.

In fact, although most researches (see, for example, Eccles \& Mavrinac, 1995; Taffler \& Breton, 2001) sustain that analysts mainly refer to financial statement data in forecasting earnings, there are also studies showing both that the MD\&A statement is the most important source of information cited in the analysts' reports (Previts, Bricker, Robinson, \& Young, 1994; Rogers \& Grant, 1997) and that the MD\&A disclosure affects financial analysts' forecasts (Barron, Kile, \& O’Keefe, 1999; Beretta \& Bozzolan, 2008; Bryan, 1997; Pisano, 2010). However, the studies showing the usefulness of MD\&A for financial analysts are few and, for this reason, Ramnath et al. (2008) called for researches in order to better understand the relationship between the information really used by analysts and their forecasts.

This paper responds to the previous call for research by examining whether the MD\&A disclosures provided after the issuing of both Directive 2003/51/EC and the IFRS Practice Statement affect the properties of analysts' forecasts. We developed a multidimensional measure to assess the MD\&A disclosure quality and hypothesized that greater accuracy and less dispersion in analysts' forecasts are associated with higher levels of MD\&A disclosure quality.

We conducted our analysis on a sample of Italian non-financial listed companies. The choice to focus on the Italian context is largely due to two considerations. Firstly, the MD\&A disclosure regulation has been modified by Legislative Decree 32/2007, which implemented the Accounts Modernisation Directive 2003/51/EC. Secondly, little is still known about the content of the MD\&A and its effect on analysts' forecasts among Italian companies.

We found that our measure of MD\&A disclosure quality is significantly and positively related to forecast accuracy. We conducted other analyses in order to better understand the previous relationship and we found that, if we analyze the different information contained in the MD\&A statement, financial analysts consider useful accounting and financial data in forecasting earnings.

The paper's structure is organized as follows. In Section 2, we provide a description of the MD\&A disclosure according to the EU law and the guidance issued by the IASB and we review previous literature concerning the usefulness of MD\&A for analysts, developing our hypotheses. Section 3 presents our measure of MD\&A disclosure quality. In Section 4, the sample and research method are described. Section 5 illustrates and discusses the results emerging from the analysis. Finally, Section 6 draws some conclusions, limitations, and suggestions for future research.

\section{Background and Literature Review}

\section{The MD\&A Requirements Under the EU's Law and the IFRS Practice Statement on Management Commentary}

The Fourth Council Directive 78/660/EEC of 25 July 1978 introduced the requirement to prepare an MD\&A statement, whose function is to complement the information contained in the financial statement by 
providing a review of the development of the company's business and its position (Art. 46, Paragraph 1). ${ }^{1}$ In addition to this general requirement, Paragraph 2 of Art. 46 requires firms to provide a description of some specific topics, such as the activities in the field of research and development (R\&D), the company's likely future development, etc..

Considering the legal requirements, it is possible to affirm that although the MD\&A is a mandatory document, its content is both mandatory and voluntary. Except for the specific topics compulsorily required by Paragraph 2 of Art. 46, firms are free to decide both the information to provide in their MD\&A and the format for its presentation. For this characteristic, some scholars define the MD\&A statement as both an open document (Giunta \& Pisani, 2005) and the natural place for voluntary disclosures (Quagli, 2004).

In 2003, the EU issued the Accounts Modernisation Directive 2003/51/EC, which broadened the content of the first paragraph of Art. 46, requiring firms to provide more information in their MD\&A.

The new Art. 46 confirms the MD\&A's function of complementing the information contained in the financial statement. However, it requires firms to discuss more information, such as the principal risks and uncertainties that the company faces, financial and non-financial key performance indicators, and the information relating to environmental and personnel matters, which could allow financial statement users to better understand the company's business and position. ${ }^{2}$

Moreover, the new paragraph makes explicit a new function of the MD\&A, that is to review the data contained in the financial statement (De Sarno, 2007), providing further financial information. This function is highlighted by the requirements of including both financial indicators and references to and additional explanations of amounts reported in the financial statement in the MD\&A.

Although the new Art. 46 requires firms to discuss and analyze more topics, the format for their presentation and the information to disclose for each topic continue to be deliberately not specified however. As a consequence, it is possible to find great variety across firms and industries in the information released in their MD\&A.

The Accounts Modernisation Directive was implemented by the EU member states in different years. In Italy, it was implemented through Legislative Decree 32/2007, which became effective for reports for the financial years beginning on or after April 12, 2007.

The relevance of the MD\&A statement has been recognized also by the IASB, which issued the IFRS Practice Statement "Management Commentary" in December 2010. This represents a non-binding guidance for the presentation of the MD\&A. In particular, the guidance suggests a framework that companies could follow in drawing up their MD\&A, illustrating the principles that management should fulfill and the elements that should be discussed.

With respect to the first point, the MD\&A should contain all the information necessary to an external financial statement user to understand the management's view of the company’s performance, position and progress, and it should supplement and complement the information presented in the financial statement (IASB, 2010, Par. 12).

\footnotetext{
${ }^{1}$ According to some scholars, this function could be achieved by including in the MD\&A information about the external environment, strategy, and results of the company (Bagnoli, 2003; Caratozzolo, 1998; Colucci \& Riccomagno, 1999; Giunta \& Pisani, 2005; Guerini \& Comoli, 1988).

${ }^{2}$ Consistent with this aim, in 2006, the EU issued Directive 2006/46/EC which amended the Fourth Council Directive, introducing Art. 46a. According to Art. 46a, a company whose securities are admitted to trading on a regulated market shall provide a description of corporate governance structure in its annual report.
} 
To align with these principles, the guidance clearly suggests including both forward-looking information and information that possesses the qualitative characteristics illustrated in the Conceptual Framework in the MD\&A.

Passing to the second point, the IFRS Practice Statement sets out the following five elements to discuss in the MD\&A (IASB, 2010, Par. 24):

(1) The nature of the business;

(2) Management's objectives and its strategies for meeting those objectives;

(3) The company's most significant resources, risks, and relationships;

(4) The results of operations and prospects;

(5) The critical performance measures and indicators that management uses to evaluate the company's performance against stated objectives.

Compared to the content of the Fourth Council Directive, it seems that the elements suggested by the IFRS Practice Statement to discuss in the MD\&A are very similar to those required by Art. 46 (see Table 1). This is because in developing the guidance, the board took into account the requirements on narrative reporting in place in a variety of jurisdictions and, among these, the EU requirement.

Table 1

The Topics to Discuss in the MD\&A Statement

\begin{tabular}{|l|l|}
\hline $\begin{array}{l}\text { IFRS Practice Statement “Management Commentary" } \\
\begin{array}{l}\text { The nature of the business } \\
\text { Management's objectives and its strategies for meeting } \\
\text { those objectives }\end{array}\end{array}$ & Fourth Council Directive \\
\hline $\begin{array}{l}\text { The company's most significant resources, risks, and of the company's position } \\
\text { relationships }\end{array}$ & $\begin{array}{l}\text { The description of the principal risks and uncertainties that the } \\
\text { company faces } \\
\text { The company's financial risk management objectives and policies } \\
\text { The company's exposure to price risk, credit risk, liquidity risk, and } \\
\text { cash flow risk }\end{array}$ \\
\hline The results of operations and prospects & $\begin{array}{l}\text { A review of the development and performance of the company's } \\
\text { business: financial indicators and references to and aditional } \\
\text { explanations of amounts reported in the financial statement } \\
\text { Any important events that have occurred since the end of the financial } \\
\text { year } \\
\text { The company's likely future development }\end{array}$ \\
\hline $\begin{array}{l}\text { The critical performance measures and indicators that } \\
\text { management uses to evaluate the company's performance } \\
\text { against stated objectives }\end{array}$ & \begin{tabular}{l} 
Non-financial key performance indicators \\
\hline Information relating to environmental matters \\
Information relating to personnel matters \\
Activities in the field of R\&D \\
Information concerning the acquisitions of own shares \\
The existence of branches of the company \\
A description of corporate governance structure
\end{tabular} \\
\hline
\end{tabular}

However, Art. 46 requires companies to discuss more information in their MD\&A compared to that suggested by the IASB, such as the information relating to environmental and employee matters and the activities in the field of R\&D.

Alike to the Fourth Council Directive, the IFRS Practice Statement does not specify the items of information to disclose for each element and the format for their presentation. 
Differently from the European Directive, the IASB guidance places more emphasis on forward-looking information to include in the MD\&A. This could be due to the nature of the IFRS Practice Statement, that is, a non-binding guidance rather than a compulsory rule.

\section{The Usefulness of MD\&A Disclosure for Financial Analysts}

Although most studies (Eccles \& Mavrinac, 1995; Epstein \& Palepu, 1999; McEwen \& Hunton, 1999) found that the financial statement, in particular the income statement, is the most important source of information to analysts, there are also scholars showing the prevalent role played by the MD\&A statement. By way of example, Rogers and Grant (1997) found that the MD\&A provides the largest proportion of annual report information cited by analysts. Clarkson et al. (1999) showed that MD\&A is considered a source of new and useful information by financial analysts and Eccles and Lupone (2000) found that these users assign more importance to non-monetary data, which are mainly released in the MD\&A, rather than to accounting information.

In line with this result, Previts et al. (1994) investigated the type of information reported by analysts and found that they extensively disclose and evaluate non-financial information. Taffler and Breton (2001) linked the information cited in the analysts' reports to their recommendation and found that analysts are concerned with the firm's management, strategy, and competitive environment (information disclosed in the MD\&A statement) in arriving at their investment recommendations.

Other scholars further examined the relationship between MD\&A disclosure and analysts' forecasts, hypothesizing that the higher the disclosure level, the better the analysts' forecasts in terms of increased accuracy and decreased dispersion (Healy \& Palepu, 2001; Hope, 2003; Lang \& Lundholm, 1996). The first study was developed by Bryan (1997) who found that the information on future, volume, and revenue contained in the MD\&A was positively associated with the sales forecast revision. Barron et al. (1999) showed that the MD\&A quality, as assessed by the Securities and Exchange Commission (SEC), was associated with less error and less dispersion in analysts' forecasts, and Barton and Mercer (2005) found that the release of plausible management's performance explanations increases analysts' earnings forecasts. In the Italian context, Beretta and Bozzolan (2008) found that the MD\&A disclosure quality of forward-looking information was positively associated with accuracy and negatively associated with the dispersion of financial analysts' forecasts, and Pisano (2010; 2011) showed that the level of MD\&A disclosures was positively related to forecast accuracy.

On the basis of the previous arguments ${ }^{3}$, we developed the following two hypotheses:

$\mathrm{H}_{1}$ : MD\&A disclosure quality is positively associated with accuracy in analysts' earnings forecasts.

$\mathrm{H}_{2}$ : MD\&A disclosure quality is negatively associated with dispersion in analysts' earnings forecasts.

\section{A Multidimensional Measure to Assess the Quality of MD\&A Disclosures}

To assess the MD\&A disclosure quality, we developed a multidimensional measure. To evaluate the extent of narrative disclosures, most studies have suggested quantity disclosure indices, assuming the quantity as a proxy for disclosure quality. However, these indices are not able to evaluate all dimensions of disclosure quality, because they are unidimensional measures (Beattie et al., 2004). For this reason, the measurement of the quality of disclosure is recognized as a relevant question that is still open (Cole \& Jones, 2005; Healy \& Palepu, 2001) and the need to develop more effective measures for disclosure quality is emphasized in literature (Core, 2001).

\footnotetext{
3 To support our hypotheses, we also measured the analysts' forecast accuracy for the sampled companies in both 2007 and 2008 (the years before and after the implementation of Directive 2003/51/EC in Italy) and found that it increased. The result of the $t$-test showed that the difference between the means is significant.
} 
Some scholars responded to the previous call for research, developing different multidimensional measures of disclosure quality. The first one has been suggested by Beattie et al. (2004), who considered two dimensions: the amount of disclosure and its spread across the Jenkins report's topics. Other multidimensional measures were provided by Beretta and Bozzolan in 2004 and 2008. In the first article, the authors identified four dimensions of risk disclosure quality: the content, the economic sign attributed to the expected impact, the type of measures, and the outlook orientation. In the second article, the authors identified two dimensions of forward-looking disclosure quality: the quantity and the richness, that is the width (both coverage of and dispersion across the topics identified) and the depth (type of measure used, expected impact on future performance, and outlook profile) of the information.

This study also responds to the calls for research of Core (2001), developing a measure to assess the quality of MD\&A disclosures. We considered three dimensions: the quantity of disclosures released (DQuantity), the spread of disclosures across different topics $(S p D)$, and the attributes of disclosures $(A t D)$. We computed our measure of MD\&A disclosure quality (MD\&ADQuality) averaging these three dimensions.

With respect to DQuantity, we measured this dimension in terms of relative number of sentences released by each firm in its MD\&A for some specific items of information, adjusted for size and industry. We defined the items of information to discuss in the MD\&A ex ante, using the requirements of Art. 46 and the guidance issued by the IASB, as well as previous studies on the MD\&A statement's content (Bryan, 1997; Callahan \& Smith, 2004; Chandra, Ettredge, \& Stone, 2006; Hooks \& Moon, 1993; Holder-Webb, 2007; Morgan, 2008 for US companies; Bagnoli, 2003; Beretta \& Bozzolan, 2004; 2008; Carini, Veneziani, Bendotti, \& Teodori, 2014; Dainelli, Bini, \& Giunta, 2010; Ginesti, Macchioni, Sannino, \& Spano, 2013; Greco, 2010; Pisano, 2010; 2011 for Italian companies). ${ }^{4}$ We identified 103 items of information that a firm should provide in its MD\&A. These items were classified into 13 topics, and these topics were grouped into the following four categories:

(1) Business description;

(2) Review of accounting and financial data;

(3) Additional information;

(4) Specific topics.

On one hand, the first and fourth categories include information that firms should discuss according to the previous Art. 46. On the other hand, the second and third categories include information that firms should provide according to the new MD\&A requirements, after the issuing of the European Directive.

Once the overall amount of MD\&A disclosures provided by each company was computed, we measured the relative quantity of disclosure (DQuantity ${ }^{r}$ ) as the standardized residual of an ordinary least squares (OLS) regression having the size and industry as independent variables (Beretta \& Bozzolan, 2004). The regression model was: $\bar{D} Q$ uantity $=\alpha+\beta_{1}$ Industry $+\beta_{2}$ Size , and the DQuantity ${ }^{r}$ was obtained as:

$$
\text { DQuantity }{ }_{i}^{r}=\text { DQuantity }_{i}-\widehat{D} Q u a n t i t y_{i}
$$

where: DQuantity ${ }_{i}^{r}=$ Relative quantity of disclosure for company $i$; DQuantity $y_{i}=$ Observed disclosure for company $i$; $\bar{D} Q u a n t i t y_{i}=$ Estimated disclosure for company $i$.

\footnotetext{
${ }^{4}$ Considering that we applied the framework to Italian companies, we referred also to the guidance that the Italian professional standards setter issued in 2009 to help firms in preparing their MD\&A statements after the implementation of Directive 2003/51/EC (Consiglio Nazionale dei Dottori Commercialisti e degli Esperti Contabili [CNDCEC], 2009a; 2009b).
} 
This index is greater when the company discloses more information than the average of firms belonging to the same industry, adjusted for size.

The first dimension is useful to determine how much information firms provide in their MD\&A. In this way, we can also verify the impact of new EU requirements on the companies' disclosure behavior.

Moving to the second dimension, we measured $S p D$ across different topics using the Herfindahl index (Beattie et al., 2004). In particular, we were interested in the spread of information across the four categories previously identified. So, $S p D$ was calculated as:

$$
\operatorname{Sp} D_{i}=\sum_{j=1}^{n} p_{i j}^{2}
$$

where: $S p D_{i}=$ Spread of disclosures for company $i ; p_{i j}=$ Proportion of disclosures provided by company $i$ in category $j ; j=$ Number of categories of information identified.

This index can vary from $1 / n$, when the sentences are spread, to 1 , when all the sentences fall into one category. In other words, the higher the value of the index, the poorer the spread. Because we were interested in the spread of disclosures, we reversed the index (i.e., $1-S p D i$ ), so that the higher the value of the index, the better the spread.

The second dimension is useful to appreciate both the completeness of the MD\&A and the relevance recognized by each firm to different topics. We considered that MD\&A quality is higher when firms provide information on all the categories identified.

The third dimension considers the attributes of disclosures, which are time orientation (forward-looking/present/historical), type (financial/non-financial), and nature (qualitative/quantitative).

The decision to analyze the time orientation of the information derived from the relevance recognized by academics, regulatory, and professional bodies to forward-looking information. In line with this consideration, the EU encourages firms to include forward-looking information in their MD\&A since 1978, requiring them to provide a description of the company's likely future development, and the IASB sustains that management should release forward-looking information in order to align with the principles suggested in the guidance. Moreover, the decision to investigate the type of the information derived from the choice of the EU to make explicit a new function of the MD\&A, that is to review the data contained in the financial statement, providing further financial information. Finally, we chose to examine the nature of the information because the EU decided not to require a specific format for its presentation in the MD\&A. However, the new requirement to include in the MD\&A both financial and non-financial key performance indicators highlights the relevance recognized to quantitative information. So, similarly to other scholars (Botosan, 1997; Holder-Webb, 2007; Morgan, 2008), we decided to weight quantitative information more heavily than qualitative information.

The time orientation of the information $(T o D)$ was measured as:

$$
T o D_{i}=\frac{1}{2} \frac{1}{s d_{i}} \sum_{j=1}^{s d_{i}} T o_{i j}
$$

where: $T o D_{i}=$ Time orientation of disclosures for company $i$; $s d_{i}=$ Number of sentences disclosed by company $i$ for the items of information identified; $T o_{i j}=2$ if the information disclosed in the sentence $j$ of the MD\&A of company $i$ is forward-looking, 1 if the information disclosed in the sentence $j$ of the MD\&A of company $i$ is historical, and 0 if the information disclosed in the sentence $j$ of the MD\&A of company $i$ is present.

This index can vary from 0 to 1 and is higher when the company releases more forward-looking information. 
The type of the information $(T y D)$ was computed as:

$$
T y D_{i}=\frac{1}{s d_{i}} \sum_{j=1}^{s d_{i}} T y D_{i j}
$$

where: $T y D_{i}=$ Type of disclosures for company $i ; s d_{i}=$ Number of sentences disclosed by company $i$ for the items of information identified; $T y D_{i j}=1$ if the information disclosed in the sentence $j$ of the MD\&A of company $i$ is financial and 0 if the information disclosed in the sentence $j$ of the MD\&A of company $i$ is non-financial.

This index can range between 0 and 1 and is higher when the company discloses more financial information.

The nature of the information $(\mathrm{NaD})$ was calculated as:

$$
N a D_{i}=\frac{1}{s d_{i}} \sum_{j=1}^{s d_{i}} N a D_{i j}
$$

where: $N a D_{i}=$ Nature of disclosures for company $i ; s d_{i}=$ Number of sentences disclosed by company $i$ for the items of information identified; $N a D_{i j}=1$ if the information disclosed in the sentence $j$ of the MD\&A of company $i$ is quantitative and 0 if the information disclosed in the sentence $j$ of the MD\&A of company $i$ is qualitative.

This index can vary from 0 to 1 and is higher when the company provides more quantitative information.

The $A t D$ index was measured as the average of $T o D, T y D$, and $N a D$ indices:

$$
A t D_{i}=\frac{1}{3}\left(T o D_{i}+T y D_{i}+N a D_{i}\right)
$$

Finally, the measure of MD\&ADQuality was obtained averaging DQuantity ${ }^{r}$, $S p D$, and AtD. However, before averaging these three dimensions and in order to avoid a scale effect, the previous indices were standardized as follows:

$$
\operatorname{Ind}_{i}^{S}=\frac{\operatorname{Ind}_{i}-\min (\text { Ind })}{\max (\operatorname{Ind})-\min (\text { Ind })}
$$

where: $I n d_{i}^{s}=$ Standardized index for company $i$; $\operatorname{Ind}_{i}=$ Observed index for company $i$.

The final measure of MD\&A disclosure quality was obtained as follows:

$$
M D \& A D Q u a l i t y_{i}=\frac{1}{3}\left(\text { DQuantity }_{i}^{r s}+S p D_{i}^{s}+A_{t} D_{i}^{s}\right)
$$

\section{Sample and Research Method}

\section{Sample Selection and Data Collection}

The sample is composed of 59 non-financial companies listed in both 2008 and 2009 on the Italian Stock Exchange. Bank and insurance companies have been excluded because they draw up their financial statements according to different regulations from the other sectors, making the financial statements of the former basically impossible to compare with those of the latter. The years 2008 and 2009 have been chosen because firms have the latest MD\&A requirements after the implementation of Directive 2003/51/EC.

Once the sample was defined, the MD\&A statements for both 2008 and 2009 were gathered from the website of each listed company. Accounting and financial data were taken from AIDA, the analysts' earnings forecasts were taken from IBES, and information on stock prices was taken from COMPUSTAT. 


\section{Research Methodology}

In order to test the hypotheses developed, we used the following OLS regression models:

ForAcc $=\alpha+\beta_{1} M D \& A D Q u a l i t y+\beta_{2}$ Size $+\beta_{3}$ Prof $+\beta_{4}$ Debt $+\beta_{5}$ Ind $+\beta_{6}$ AnFol $+\beta_{7}$ EarnSur $+\varepsilon$

ForDisp $=\alpha+\beta_{1} M D \& A D Q u a l i t y+\beta_{2}$ Size $+\beta_{3}$ Prof $+\beta_{4}$ Debt $+\beta_{5}$ Ind $+\beta_{6}$ AnFol $+\beta_{7}$ EarnSur $+\varepsilon$

Following Beretta and Bozzolan (2008), Hope (2003), and Lang and Lundholm (1996), we defined forecast accuracy (ForAcc) as the negative of the absolute value of the analyst forecast error deflated by stock price:

$$
\text { ForAcc }=-\frac{\left|\overline{E P S_{t}}-E P S_{t}\right|}{P P S_{t}}
$$

where: $\overline{E P S_{t}}=$ Median analysts' forecasts of EPS in period $t$; $E P S_{t}=$ Earnings per share in period $t$; and $P P S_{t}=$ Price per share at the beginning of period $t$.

In addition, we defined forecast dispersion (ForDisp) as the standard deviation of analysts' forecasts deflated by stock price:

$$
\text { ForDisp }=\frac{\sqrt{\sum_{j=1}^{n} \frac{\left(E P S_{j t}-E \hat{P} S_{t}\right)^{2}}{j}}}{P P S_{t}}
$$

where: $E P S_{j t}=$ Analyst $j$ 's earnings per share for period $t ; E \hat{P} S_{t}=$ Mean of earnings per share in period $t$; $P P S_{t}=$ Price per share at the beginning of period $t$; and $j=$ Number of analysts following the firm.

As independent variable, we considered the MD\&ADQuality provided by each company for both 2008 and 2009. To measure this variable, we used the content analysis (Krippendorf, 1980). The research method was organized as follows. Firstly, we identified the items of information that a firm should discuss in its MD\&A as discussed in Section 3.

Then, the MD\&A statements were analyzed for each company, and data were collected for each item of information. We chose the sentences as recording units. The decision to focus on the sentences derived from the consideration that both the EU and the IASB did not specify the information to release for each topic. So, companies could voluntarily decide the items of information to disclose and, as a consequence, the analysis of the sentences could permit a better understanding of the disclosure behavior adopted by each firm.

Each sentence was coded according to its content, time orientation, type, and nature of the information disclosed, by using the software QSR NVivo 8.

The analysis was conducted by a senior researcher and an assistant researcher. To align the set of coding rules, a preliminary test was conducted among coders. In particular, two MD\&As were coded independently, in order to identify the differences among coders. Then, these differences were discussed and, on the basis of this discussion, the final set of coding rules was defined.

Once the MD\&A statements of each company were read, a score was assigned to each firm, equal to the amount of sentences disclosed for the overall items of information identified. In this way, we computed the overall amount of MD\&A disclosures provided and then the MD\&ADQuality variable for each firm.

To isolate the relationship between analysts' earnings forecasts and the independent variable, we included the following control variables that previous researchers have found to be associated with analysts' forecasts (Hope, 2003; Lang \& Lundholm, 1996): firm size (Size) measured as the natural logarithm of sales; profitability 
(Prof) computed as the return on equity; debt (Debt) calculated as the debt/equity ratio; industry (Ind) defined using the classification proposed by Borsa Italiana Spa; analysts following ( $\mathrm{AnFol}$ ) measured as the number of analysts following the firm; and earnings surprise (EarnSur) computed as the absolute value of the difference between the current year's earnings per share and last year's earnings per share, divided by the stock price at the beginning of the fiscal year.

The first three variables represent firm characteristics and were included because they could influence the analyst's decision to follow the company and gather information about it. By way of example, analysts could be interested in collecting data about bigger firms, rather than smaller ones (Lang \& Lundholm, 1996). The control variable for industry was included because it could be possible that some industries are more stable over time than others (Hope, 2003). The analysts following variable was inserted because the number of analysts could affect the properties of earnings forecasts. Finally, the earnings surprise variable was included because the variability of earnings could increase the difficulty of forecasting.

\section{Empirical Findings}

\section{Descriptive Statistics}

Table 2 shows descriptive statistics for all the variables included in the analysis. On average, the size of the sampled companies is 5.870 and the profitability is 9.509. Moreover, the Italian firms analyzed do not present high values of variability of earnings (EarnSur $=-0.043$ ) and are bank-oriented companies $(D e b t=0.771)$. The mean of the number of analysts following the firm is 7 .

Table 2

Descriptive Statistics

\begin{tabular}{|c|c|c|c|c|c|}
\hline & Mean & Std. dev. & Min. & 50th pct. & Max. \\
\hline \multicolumn{6}{|l|}{ Independent variable } \\
\hline MD\&A disclosure quality & 0.548 & 0.078 & 0.334 & 0.547 & 0.740 \\
\hline \multicolumn{6}{|c|}{ Dimensions of MD\&A disclosure quality } \\
\hline MD\&A disclosure quantity & 494.690 & 300.420 & 96.000 & 420.000 & $1,340.000$ \\
\hline DQuantity $^{r s}$ & 0.411 & 0.216 & 0.000 & 0.406 & 1.000 \\
\hline$S p D^{s}$ & 0.764 & 0.187 & 0.000 & 0.815 & 1.000 \\
\hline$A t D^{s}$ & 0.468 & 0.214 & 0.000 & 0.471 & 1.000 \\
\hline \multicolumn{6}{|l|}{ Dependent variables } \\
\hline Forecast accuracy & -0.012 & 0.109 & -0.888 & -0.004 & 0.267 \\
\hline Forecast dispersion & 0.011 & 0.016 & 0.000 & 0.007 & 0.156 \\
\hline \multicolumn{6}{|l|}{ Control variables } \\
\hline Firm size & 5.870 & 0.586 & 4.542 & 5.898 & 7.043 \\
\hline Profitability & 9.509 & 14.471 & -95.450 & 8.700 & 37.610 \\
\hline Debt & 0.771 & 0.734 & 0.000 & 0.560 & 3.560 \\
\hline Analysts following & 7.616 & 6.805 & 1.000 & 6.075 & 28.600 \\
\hline Earnings surprise & -0.043 & 0.155 & -1.138 & -0.015 & 0.435 \\
\hline
\end{tabular}

To evaluate the MD\&ADQuality, we pooled the data collected for both 2008 and 2009. The decision to pool the data derived from the consideration that we want to examine whether the disclosures provided in the MD\&A statement are considered useful by financial analysts in forecasting earnings in general, and not with reference to a specific year.

Table 2 shows that $M D \& A D Q u a l i t y$ is, on average, equal to 0.548 . 
Passing to the analysis of the three dimensions of MD\&ADQuality, Table 2 shows that, on average, Italian companies provided 494.690 sentences in their MD\&A in 2008 and 2009. If we consider the relative quantity of disclosure (DQuantity ${ }^{r}=0.411$ ), it emerges that it is affected by both size and industry (see Table 3, which reports the results of the OLS regression for DQuantity ${ }^{r}$ ). It means that the amount of disclosures provided by each firm depends on both the dimension of the company and the sector in which it operates.

Table 3

OLS Regression Model for Relative Disclosure Quantity

\begin{tabular}{lc}
\hline Variable & MD\&A disclosure quantity \\
\hline \multirow{2}{*}{ Constant } & -737.740 \\
Firm size & $(-3.032)^{* * *}$ \\
\hline \multirow{2}{*}{ Industry } & 238.447 \\
& $(5.987)^{* * *}$ \\
$R$ & -48.634 \\
$R$-squared & $(-3.493)^{* * *}$ \\
Adjusted $R$-squared & 118 \\
$F$-statistic & 0.556 \\
\hline
\end{tabular}

Note. ${ }^{* * *}: p<0.01$.

Table 4 specifies the content of Italian companies’ MD\&A.

Table 4

The Content of Italian Companies’ MD\&A

\begin{tabular}{|c|c|c|c|c|c|c|c|c|c|c|}
\hline \multirow[t]{2}{*}{ Category and topic } & \multicolumn{2}{|c|}{$\%$ of firms } & \multicolumn{2}{|c|}{ Mean of sentences } & \multicolumn{2}{|c|}{$\begin{array}{l}\text { Std. dev. of } \\
\text { sentences }\end{array}$} & \multicolumn{2}{|c|}{ No. of sentences } & \multicolumn{2}{|c|}{$\%$ of sentences } \\
\hline & 2008 & 2009 & 2008 & 2009 & 2008 & 2009 & 2008 & 2009 & 2008 & 2009 \\
\hline Business description & & & & & & & 8,045 & 8,766 & 29.77 & 27.96 \\
\hline External environment & 96 & 94 & 45.27 & 49.06 & 62.58 & 69.02 & 2,671 & 2,895 & 9.88 & 9.23 \\
\hline Strategy & 96 & 100 & 35.98 & 45.98 & 43.72 & 51.78 & 2,123 & 2,713 & 7.86 & 8.65 \\
\hline Results & 100 & 100 & 55.10 & 53.52 & 102.90 & 86.16 & 3,251 & 3,158 & 12.03 & 10.07 \\
\hline $\begin{array}{l}\text { Review of accounting } \\
\text { and financial data }\end{array}$ & & & & & & & 11,190 & 11,244 & 41.41 & 35.87 \\
\hline Income statement & 100 & 100 & 111.30 & 128.76 & 61.82 & 72.58 & 6,567 & 7,597 & 24.30 & 24.23 \\
\hline Balance sheet & 100 & 100 & 78.35 & 61.81 & 49.49 & 45.38 & 4,623 & 3,647 & 17.11 & 11.63 \\
\hline Additional information & & & & & & & 3,538 & 6,865 & 13.09 & 21.90 \\
\hline Risks and uncertainties & 96 & 98 & 39.61 & 84.44 & 27.06 & 65.26 & 2,337 & 4,982 & 8.65 & 15.89 \\
\hline Environment & 66 & 71 & 7.25 & 9.93 & 14.15 & 16.24 & 428 & 586 & 1.58 & 1.87 \\
\hline Personnel & 93 & 98 & 13.10 & 21.98 & 13.78 & 22.55 & 773 & 1,297 & 2.86 & 4.14 \\
\hline Specific topics & & & & & & & 4,251 & 4,474 & 15.73 & 14.27 \\
\hline R\&D activities & 83 & 88 & 8.42 & 13.54 & 11.13 & 19.65 & 497 & 799 & 1.84 & 2.55 \\
\hline Own shares & 74 & 74 & 5.67 & 2.93 & 5.59 & 3.08 & 335 & 173 & 1.24 & 0.55 \\
\hline Important events & 100 & 100 & 18.64 & 17.54 & 18.50 & 16.81 & 1,100 & 1,035 & 4.07 & 3.30 \\
\hline Company’s branches & 16 & 13 & 0.16 & 0.15 & 0.37 & 0.40 & 10 & 9 & 0.04 & 0.03 \\
\hline Corporate governance & 96 & 98 & 39.13 & 41.66 & 61.54 & 66.10 & 2,309 & 2,458 & 8.54 & 7.84 \\
\hline Total & & & 458.03 & 531.33 & 299.99 & 298.88 & 27,024 & 31,349 & 100.00 & 100.00 \\
\hline
\end{tabular}


All the companies released information on the following topics: results, income statement, balance sheet, and important events for both 2008 and 2009. On the other hand, the percentage of companies providing information concerning the other topics is lower. A possible explanation for these results could be that Italian companies preferred to provide much information on the income statement and balance sheet, because this information was also contained in their financial statements. So, they repeated the information provided in their financial statements in the MD\&A statement, without providing additional data. Moreover, with respect to the results and important events topics, these outcomes could be due to the decision of firms to make the financial statement users aware of the business results and the events occurred between the end of the year and the annual report's publication date, in order to permit a better understanding and contextualization of the data contained in the financial statement. However, the results reveal an increase in the percentage of firms providing information for almost all the topics and categories identified from 2008 to 2009. So, Italian companies recognized the relevance of the MD\&A statement and decided to increase the amount of information disclosed.

With respect to the information provided for each category and topic, the results show an increase in both the number of sentences disclosed from $2008(27,024)$ to $2009(31,349)$ and the mean of sentences disclosed by all the sampled companies from 2008 (458.03) to 2009 (531.33). On the other hand, the standard deviation shows high values for both the years (299.99 in 2008 and 298.88 in 2009), revealing that the disclosure behaviors adopted by Italian companies have not been homogeneous.

The category with the highest percentage of sentences disclosed for both 2008 and 2009 is review of accounting and financial data (41.41\% of the total sentences disclosed in 2008 and 35.87\% in 2009), followed by business description (29.77\% in 2008 and 27.96\% in 2009), additional information (13.09\% in 2008 and $21.90 \%$ in 2009), and specific topics (15.73\% in 2008 and 14.27\% in 2009). So, Italian firms responded in a positive way to the new legal requirements, but mainly with regard to the review of accounting and financial data category.

With regard to the additional information category, there was an increase in the percentage of sentences disclosed in 2009, compared to that provided in 2008. So, Italian companies recognized the importance of all the new MD\&A requirements, increasing the amount of information provided on the principal risks and uncertainties, the environmental and personnel matters.

Moving to the attributes of the information disclosed, Table 5 below shows that Italian companies provided more historical (74\% in 2008 and 68\% in 2009) and present (20\% in 2008 and $27 \%$ in 2009) information than forward-looking (6\% in 2008 and 5\% in 2009) information. In particular, historical information dominates almost all the review of accounting and financial data category. On the other hand, there is some forward-looking information in the business description category and in the R\&D activities and important events topics within the specific topics category.

With respect to the type of information disclosed, the results show that Italian companies provided more non-financial measures (68\% in 2008 and 75\% in 2009) than financial measures (32\% in 2008 and 25\% in 2009). In particular, financial measures dominate in the review of accounting and financial data category; conversely, non-financial measures dominate in business description, additional information, and specific topics categories. 
Finally, with respect to the nature of information disclosed, we see that Italian companies provided both qualitative ( $52 \%$ for both the years) and quantitative ( $48 \%$ for both the years) information in their MD\&A. In particular, quantitative information dominates in the review of accounting and financial data category and in the own shares topic within the specific topics category. Conversely, qualitative information dominates in the external environment and strategy topics within the business description category, in the risks and uncertainties and environment topics within the additional information category, and in the majority of topics in the specific topics category.

Table 5

The Attributes of the Information Disclosed in the Italian Companies' MD\&A

\begin{tabular}{|c|c|c|c|c|c|c|c|c|c|}
\hline \multirow{2}{*}{ Category } & \multirow{2}{*}{ Topic } & \multirow{2}{*}{ Year } & \multicolumn{3}{|c|}{ Time orientation } & \multicolumn{2}{|c|}{ Type } & \multicolumn{2}{|c|}{ Nature } \\
\hline & & & $\mathrm{H}$ & FL & $\mathrm{P}$ & F & NF & QT & QL \\
\hline \multirow{6}{*}{$\begin{array}{l}\text { Business } \\
\text { description }\end{array}$} & \multirow{2}{*}{ External environment } & 2008 & $73 \%$ & $13 \%$ & $14 \%$ & $1 \%$ & $99 \%$ & $25 \%$ & $75 \%$ \\
\hline & & 2009 & $62 \%$ & $12 \%$ & $26 \%$ & $1 \%$ & $99 \%$ & $30 \%$ & $70 \%$ \\
\hline & \multirow{2}{*}{ Strategy } & 2008 & $56 \%$ & $10 \%$ & $34 \%$ & $1 \%$ & $99 \%$ & $13 \%$ & $87 \%$ \\
\hline & & 2009 & $40 \%$ & $8 \%$ & $52 \%$ & $1 \%$ & $99 \%$ & $15 \%$ & $85 \%$ \\
\hline & \multirow{2}{*}{ Results } & 2008 & $75 \%$ & $9 \%$ & $16 \%$ & $6 \%$ & $94 \%$ & $54 \%$ & $46 \%$ \\
\hline & & 2009 & $68 \%$ & $9 \%$ & $23 \%$ & $1 \%$ & $99 \%$ & $56 \%$ & $44 \%$ \\
\hline \multirow{4}{*}{$\begin{array}{l}\text { Review of } \\
\text { accounting } \\
\text { and financial } \\
\text { data }\end{array}$} & \multirow{2}{*}{ Income statement } & 2008 & $94 \%$ & $1 \%$ & $5 \%$ & $76 \%$ & $24 \%$ & $82 \%$ & $18 \%$ \\
\hline & & 2009 & $93 \%$ & $1 \%$ & $6 \%$ & $68 \%$ & $32 \%$ & $83 \%$ & $17 \%$ \\
\hline & \multirow{2}{*}{ Balance sheet } & 2008 & $94 \%$ & $2 \%$ & $4 \%$ & $74 \%$ & $26 \%$ & $83 \%$ & $17 \%$ \\
\hline & & 2009 & $91 \%$ & $1 \%$ & $8 \%$ & $66 \%$ & $34 \%$ & $86 \%$ & $14 \%$ \\
\hline \multirow{6}{*}{$\begin{array}{l}\text { Additional } \\
\text { information }\end{array}$} & \multirow{2}{*}{$\begin{array}{l}\text { Risks and } \\
\text { uncertainties }\end{array}$} & 2008 & $54 \%$ & $3 \%$ & $43 \%$ & $7 \%$ & $93 \%$ & $15 \%$ & $85 \%$ \\
\hline & & 2009 & $39 \%$ & $6 \%$ & $55 \%$ & $4 \%$ & $96 \%$ & $22 \%$ & $78 \%$ \\
\hline & \multirow{2}{*}{ Environment } & 2008 & $65 \%$ & $4 \%$ & $31 \%$ & $0 \%$ & $100 \%$ & $9 \%$ & $91 \%$ \\
\hline & & 2009 & $47 \%$ & $5 \%$ & $48 \%$ & $0 \%$ & $100 \%$ & $12 \%$ & $88 \%$ \\
\hline & \multirow{2}{*}{ Personnel } & 2008 & $90 \%$ & $1 \%$ & $9 \%$ & $2 \%$ & $98 \%$ & $52 \%$ & $48 \%$ \\
\hline & & 2009 & $75 \%$ & $2 \%$ & $23 \%$ & $0 \%$ & $100 \%$ & $46 \%$ & $54 \%$ \\
\hline \multirow{10}{*}{$\begin{array}{l}\text { Specific } \\
\text { topics }\end{array}$} & \multirow{2}{*}{ R\&D activities } & 2008 & $78 \%$ & $6 \%$ & $16 \%$ & $10 \%$ & $90 \%$ & $14 \%$ & $86 \%$ \\
\hline & & 2009 & $58 \%$ & $7 \%$ & $35 \%$ & $3 \%$ & $97 \%$ & $13 \%$ & $87 \%$ \\
\hline & \multirow{2}{*}{ Own shares } & 2008 & $92 \%$ & $3 \%$ & $5 \%$ & $47 \%$ & $53 \%$ & $71 \%$ & $29 \%$ \\
\hline & & 2009 & $78 \%$ & $4 \%$ & $18 \%$ & $0 \%$ & $100 \%$ & $63 \%$ & $37 \%$ \\
\hline & \multirow{2}{*}{ Important events } & 2008 & $83 \%$ & $9 \%$ & $8 \%$ & $10 \%$ & $90 \%$ & $40 \%$ & $60 \%$ \\
\hline & & 2009 & $67 \%$ & $10 \%$ & $23 \%$ & $2 \%$ & $98 \%$ & $37 \%$ & $63 \%$ \\
\hline & \multirow{2}{*}{ Company's branches } & 2008 & $60 \%$ & $0 \%$ & $40 \%$ & $0 \%$ & $100 \%$ & $0 \%$ & $100 \%$ \\
\hline & & 2009 & $56 \%$ & $0 \%$ & $44 \%$ & $0 \%$ & $100 \%$ & $11 \%$ & $89 \%$ \\
\hline & \multirow{2}{*}{ Corporate governance } & 2008 & $61 \%$ & $1 \%$ & $38 \%$ & $3 \%$ & $97 \%$ & $20 \%$ & $80 \%$ \\
\hline & & 2009 & $46 \%$ & $2 \%$ & $52 \%$ & $1 \%$ & $99 \%$ & $20 \%$ & $80 \%$ \\
\hline \multirow{2}{*}{ Total } & & 2008 & $74 \%$ & $6 \%$ & $20 \%$ & $32 \%$ & $68 \%$ & $48 \%$ & $52 \%$ \\
\hline & & 2009 & $68 \%$ & $5 \%$ & $27 \%$ & $25 \%$ & $75 \%$ & $48 \%$ & $52 \%$ \\
\hline
\end{tabular}

Note. $\mathrm{H}$ = Historical; FL = Forward-looking; P = Present; F = Financial; NF = Non-financial; QT = Quantitative; QL = Qualitative.

\section{MD\&A Disclosure Quality and Analysts’ Earnings Forecasts}

Table 6 (Mod. 1) reports results from the OLS regressions of ForAcc and ForDisp on MD\&ADQuality, providing evidence for the hypotheses developed. 
With regard to the relation between ForAcc and MD\&ADQuality, the findings support $\mathrm{H}_{1}$ that predicted a positive relationship. In fact, Table 6 (Mod. 1) shows that the estimated coefficient on the MD\&ADQuality is significantly positive at better than $5 \%$ level $(\beta=0.084, p<0.05)$ for ForAcc. Consistent with the results of previous studies, the analysts' earnings forecasts are more accurate for firms disclosing higher levels of $M D \& A D Q$ uality. This finding suggests that financial analysts are not interested only in the quantity of information disclosed for forecasting earnings, but they consider also important the spread of disclosures across the topics and the attributes of the information released. So, this result shows that the measure proposed captures dimensions of disclosure quality that are considered useful by financial analysts in forecasting earnings.

Table 6

OLS Regressions for the Relationship Between Forecast Accuracy and Dispersion and MD\&A Disclosure

\begin{tabular}{|c|c|c|c|c|c|c|}
\hline \multirow{2}{*}{ Category } & \multicolumn{3}{|c|}{ Forecast accuracy } & \multicolumn{3}{|c|}{ Forecast dispersion } \\
\hline & Mod. 1 & Mod. 2 & Mod. 3 & Mod. 1 & Mod. 2 & Mod. 3 \\
\hline Industry & $\begin{array}{c}0.023 \\
(0.556)\end{array}$ & $\begin{array}{c}0.053 \\
(1.229)\end{array}$ & $\begin{array}{c}0.044 \\
(0.985)\end{array}$ & $\begin{array}{c}-0.057 \\
(-0.615)\end{array}$ & $\begin{array}{c}-0.057 \\
(-0.591)\end{array}$ & $\begin{array}{c}-0.077 \\
(-0.783)\end{array}$ \\
\hline Firm size & $\begin{array}{l}0.164 \\
(3.192)^{* * *}\end{array}$ & $\begin{array}{c}0.109 \\
(1.888)^{*}\end{array}$ & $\begin{array}{c}0.112 \\
(1.878)^{*}\end{array}$ & $\begin{array}{c}0.073 \\
(0.632)\end{array}$ & $\begin{array}{c}0.074 \\
(0.575)\end{array}$ & $\begin{array}{c}0.046 \\
(0.345)\end{array}$ \\
\hline Profitability & $\begin{array}{l}0.181 \\
(2.909)^{* * *}\end{array}$ & $\begin{array}{l}0.178 \\
(2.827)^{* * *}\end{array}$ & $\begin{array}{l}0.161 \\
(2.514)^{* * *}\end{array}$ & $\begin{array}{c}-0.098 \\
(-0.699)\end{array}$ & $\begin{array}{c}-0.098 \\
(-0.698)\end{array}$ & $\begin{array}{c}-0.074 \\
(-0.518)\end{array}$ \\
\hline Debt & $\begin{array}{l}-0.117 \\
(-2.864)^{* * *}\end{array}$ & $\begin{array}{l}-0.115 \\
(-2.798)^{* * *}\end{array}$ & $\begin{array}{l}-0.116 \\
(-2.801)^{* * * *}\end{array}$ & $\begin{array}{c}-0.054 \\
(-0.592)\end{array}$ & $\begin{array}{c}-0.054 \\
(-0.594)\end{array}$ & $\begin{array}{c}-0.047 \\
(-0.505)\end{array}$ \\
\hline Earnings surprise & $\begin{array}{l}0.737 \\
(12.081)^{* * *}\end{array}$ & $\begin{array}{c}0.741 \\
(12.039)^{* * *}\end{array}$ & $\begin{array}{c}0.751 \\
(11.941)^{* * *}\end{array}$ & $\begin{array}{c}-0.241 \\
(-1.748)^{*}\end{array}$ & $\begin{array}{c}-0.241 \\
(-1.748)^{*}\end{array}$ & $\begin{array}{c}-0.259 \\
(-1.847)^{*}\end{array}$ \\
\hline Analysts following & $\begin{array}{l}-0.113 \\
(-2.165)^{* *}\end{array}$ & $\begin{array}{l}-0.103 \\
(-1.952)^{* *}\end{array}$ & $\begin{array}{l}-0.102 \\
(-1.918)^{* *}\end{array}$ & $\begin{array}{c}-0.130 \\
(-1.108)\end{array}$ & $\begin{array}{c}-0.130 \\
(-1.102)\end{array}$ & $\begin{array}{c}-0.112 \\
(-0.946)\end{array}$ \\
\hline MD\&A disclosure quality & $\begin{array}{l}0.084 \\
(2.070)^{* *}\end{array}$ & & & $\begin{array}{c}-0.002 \\
(-0.020) \\
\end{array}$ & & \\
\hline MD\&A disclosure quantity & & $\begin{array}{c}0.076 \\
(1.565) \\
\end{array}$ & & & $\begin{array}{c}-0.001 \\
(-0.005) \\
\end{array}$ & \\
\hline Business description & & & $\begin{array}{c}-0.022 \\
(-0.437)\end{array}$ & & & $\begin{array}{c}-0.049 \\
(-0.435)\end{array}$ \\
\hline $\begin{array}{l}\text { Review of accounting and } \\
\text { financial data }\end{array}$ & & & $\begin{array}{c}0.076 \\
(1.705)^{*}\end{array}$ & & & $\begin{array}{c}-0.060 \\
(-0.607)\end{array}$ \\
\hline Additional information & & & $\begin{array}{c}0.011 \\
(0.235)\end{array}$ & & & $\begin{array}{c}0.188 \\
(1.725)\end{array}$ \\
\hline Specific topics & & & $\begin{array}{c}0.049 \\
(0.955) \\
\end{array}$ & & & $\begin{array}{c}-0.067 \\
(-0.591)\end{array}$ \\
\hline$N$ & 118 & 118 & 118 & 118 & 118 & 118 \\
\hline$R$ & 0.910 & 0.908 & 0.911 & 0.354 & 0.354 & 0.388 \\
\hline$R$-squared & 0.828 & 0.825 & 0.829 & 0.125 & 0.125 & 0.150 \\
\hline Adjusted $R$-squared & 0.817 & 0.814 & 0.813 & 0.069 & 0.069 & 0.071 \\
\hline F-statistic & $75.645^{* * *}$ & $74.180^{* * *}$ & $51.931^{* * *}$ & $2.247^{* *}$ & $2.247^{* *}$ & $1.894^{* *}$ \\
\hline
\end{tabular}

Note. ${ }^{*}: p<0.10 ;{ }^{* *}: p<0.05 ;{ }^{* * *}: p<0.01$.

The results also show that the estimated coefficient on Size is significantly positive at better than $1 \%$ level ( $\beta=0.164, p<0.01$ ) for ForAcc. This could be because bigger companies tend to have more stakeholders requiring information on them and, as a consequence, financial analysts tend to follow these companies. 
In addition, the findings show that the estimated coefficients on both the $\operatorname{Prof}(\beta=0.181, p<0.01)$ and the EarnSur $(\beta=0.737, p<0.01)$ are significantly positive at better than $1 \%$ level for ForAcc. A possible explanation for these results could be the fact that the financial analysts tend to follow companies that achieve higher and more stable performances, because the market requires more information for these companies.

Furthermore, the results report that the estimated coefficient on Debt is significantly negative at better than 1\% level $(\beta=-0.117, p<0.01)$ for ForAcc. A possible explanation for this result could be the fact that firms with more debt are predominantly financed by banks, which can obtain private information from firms. In this context, companies tend not to provide much public information and the market tends not to require much information for them. As a consequence, financial analysts tend not to follow these companies.

The regression explains a significant proportion of the variation in ForAcc, with the adjusted $R$-squared of 0.817 .

With regard to the relation between ForDisp and MD\&ADQuality, the findings do not support $\mathrm{H}_{2}$ that predicted a negative relationship. However, Table 6 (Mod. 1) shows that the estimated coefficient on the $M D \& A D Q u a l i t y$ is negative as hypothesized $(\beta=-0.002)$, although it is not statistically significant. A possible reason for this result could be the sample size. In fact, although in line with previous studies on the disclosures provided by Italian companies in both their annual reports and MD\&A statements, the sample includes only 59 companies. However, the main constraint on sample size has been the availability of financial and analyst data for the period covered. Moreover, another reason could be that financial analysts consider too dispersive the content of the MD\&A statements drawn up according to the new regulation. However, this is only a theoretical assumption that needs to be verified with further empirical analysis.

To verify if the measure proposed really captures dimensions of disclosure quality that are considered useful by financial analysts in forecasting earnings, we examine the relationship between MD\&ADQuantity and analysts' earnings forecasts. In other words, considering the three dimensions included in our measure of $M D \& A D Q u a l i t y$, we want to understand if financial analysts find helpful only the amount of disclosure provided by each company in its MD\&A statement in forecasting earnings, or if they consider also important the other two dimensions.

Table 6 (Mod. 2) reports results from the OLS regressions of ForAcc and ForDisp on MD\&ADQuantity, showing that both the estimated coefficients on the MD\&ADQuantity ( $\beta=0.076$ for ForAcc and $\beta=-0.001$ for ForDisp) are not statistically significant. These findings confirm the usefulness of the proposed measure of MD\&ADQuality for financial analysts. In fact, they do not consider helpful only the amount of disclosure provided in forecasting earnings, but they are interested in all the three dimensions of disclosure quality, namely, the quantity, the spread across different topics, and the attributes of disclosures.

Finally, we estimated regression models replacing the overall MD\&ADQuantity variable with each of its four categories. Table 6 (Mod. 3) reports results from the OLS regressions of ForAcc and ForDisp on the components of MD\&ADQuantity.

With regard to the relation between ForAcc and the components of MD\&ADQuantity, the findings show that only the estimated coefficient on the review of accounting and financial data variable is significantly positive at better than $10 \%$ level $(\beta=0.076 ; p<0.10)$. Thus, the higher the information provided on the review of accounting and financial data category, the higher the ForAcc. This means that financial analysts consider useful accounting data for forecasting earnings. 
Moreover, with regard to the relation between ForDisp and the components of MD\&ADQuantity, the results show that all the estimated coefficients on the components of MD\&ADQuantity are not statistically significant.

\section{Concluding Remarks}

In recent years, both the EU and the IASB paid attention to the MD\&A statement in the annual report by issuing the Accounts Modernisation Directive 2003/51/EC and the IFRS Practice Statement "Management Commentary” respectively.

This study investigated the effects of the MD\&A disclosure on analysts' earnings forecasts, developing a multidimensional measure of disclosure quality.

Applying the proposed measure to the Italian context, we found that in the periods investigated Italian companies mainly released information on the data included in the financial statement and on the business description in their MD\&A and that this information is essentially historical and non-financial. These results are consistent with prior findings on the content of the Italian companies’ MD\&A statements (Greco, 2010; Pisano, 2010; 2011; Carini et al., 2014). However, we also found that Italian companies increased the information provided on the principal risks and uncertainties that the company faces, the environmental and personnel matters from 2008 to 2009. This means that the sampled companies recognized the importance of all the new MD\&A requirements, increasing the amount of information discussed on these new topics.

Moreover, we provided evidence that our measure of MD\&A disclosure quality is significantly and positively related to forecast accuracy, as suggested by the literature stream on the effects of disclosure on analysts' forecasts (Hope, 2003; Lang \& Lundholm, 1996). Put together with the result on the absence of statistical significance in the relationship between disclosure quantity and forecast accuracy, this finding suggests that financial analysts consider important all the dimensions of our measure of MD\&A disclosure quality for forecasting earnings, confirming the need to create more effective measures for disclosure quality, as an alternative to unidimensional indices, as recommended by the stream of research on disclosure quality.

Finally, we found that forecast accuracy is affected by the release of information on the review of accounting and financial data included in the financial statement in the MD\&A, i.e., financial analysts are mainly interested in accounting data to forecast earnings. This finding is in contrast to the results of previous researches on the demand of information from financial analysts in the Italian context (Avallone, 2003; Eccles \& Lupone, 2000), which found that financial analysts are mainly interested in non-financial data. A possible reason could be that our research differs from these studies in both the aim and the methodology used. In particular, we were interested in the relationship between MD\&A disclosure and analysts' forecast and used OLS regressions to investigate this phenomenon; on the other hand, both Avallone (2003) and Eccles and Lupone (2000) focused their researches on the information needs of these users and conducted telephone interviews and questionnaires to financial analysts to achieve their aim.

This research should be of interest to both academics and regulators. From the academic perspective, the research adds to the literature examining the relationship between disclosure and analysts' forecasts by showing that financial analysts found the MD\&A disclosure quality useful for forecasting earnings. Moreover, this study adds to the debate on the necessity of more effective measures for disclosure quality, suggesting a measure to assess the overall MD\&A disclosure quality on the basis of the requirements of Art. 46 of the Fourth Council Directive and the guidance issued by the IASB, which could be used for future research on the disclosure 
behavior of companies operating in other EU member states. This could permit the identification of benchmarks of disclosure quality. Finally, the paper provides insights on the disclosure behavior of Italian companies with respect to the entire narrative disclosures contained in the MD\&A statement, and not only for a single topic.

From the regulator's perspective, the findings of this research could be useful to both the EU and the IASB by providing insights on the items of information that are less disclosed by Italian companies and, consequently, on the items of information that should require some improvements. Moreover, our finding that MD\&A is an important determinant of the accuracy of analysts' forecasts suggests that the interest of both the EU and the IASB in MD\&A is not misguided and needs to be increased.

Our study presents some limitations. First of all, we conducted the analysis only in the Italian context. Moreover, the sample included only 59 non-financial companies listed on the Italian stock market, hence the results may not be generalized to all Italian companies. Finally, the study covered the MD\&A statements for both 2008 and 2009, which are the years after the implementation of Directive 2003/51/EC in Italy. Future research could extend the analysis of the content of MD\&A statement to other years before the implementation of the new MD\&A requirements and to firms operating in other countries.

\section{References}

Accounting Standards Board [ASB]. (2006). Reporting statement: Operating and financial review. London, UK: Accounting Standards Board.

American Institute of Certified Public Accountants [AICPA]. (1994). Improving business reporting—A customer focus. Meeting the information need of investors and creditors. Comprehensive report of the special committee on financial reporting (the Jenkins report). New York, NY: American Institute of Certified Public Accountants.

Avallone, F. (2003). La domanda di informazioni economico-finanziarie nei mercati dei capitali: Alcune evidenze empiriche. In D. M. Salvioni (Ed.), Trasparenza ed efficacia della comunicazione economico-finanziaria (pp. 325-352). Torino, IT: Giappichelli.

Bagnoli, C. (2003). La relazione sulla gestione tra normativa e prassi. Milano, IT: Giuffrè.

Barron, O. E., Kile, C. O., \& O’Keefe, T. B. (1999). MD\&A quality as measured by the SEC and analysts' earnings forecasts. Contemporary Accounting Research, 16(1), 75-109.

Barton, J., \& Mercer, M. (2005). To blame or not to blame: Analysts' reactions to external explanations for poor financial performance. Journal of Accounting and Economics, 39(3), 509-533.

Beattie, V., McInnes, B., \& Fearnley, S. (2004). A methodology for analyzing and evaluating narratives in annual reports: A comprehensive descriptive profile and metrics for disclosure quality attributes. Accounting Forum, 28(3), 205-236.

Beretta, S., \& Bozzolan, S. (2004). A framework for the analysis of firm risk communication. The International Journal of Accounting, 39(3), 265-288.

Beretta, S., \& Bozzolan, S. (2008). Quality versus quantity: The case of forward-looking disclosure. Journal of Accounting, Auditing, and Finance, 23(3), 333-376.

Botosan, C. A. (1997). Disclosure level and the cost of equity capital. The Accounting Review, 72(3), 323-349.

Bryan, S. H. (1997). Incremental information content of required disclosures contained in management discussion and analysis. The Accounting Review, 72(2), 285-301.

Callahan, C. M., \& Smith, R. E. (2004). Firm performance and management’s discussion and analysis disclosures: An industry approach. Proceedings from the Central States Research Conference, Kansas City, Kansas State University.

Canadian Institute of Chartered Accountants [CICA]. (2009). Management's discussion and analysis: Guidance on preparation and disclosure. Toronto, Ontario: Canadian Institute of Chartered Accountants.

Caratozzolo, M. (1998). Il bilancio d'esercizio. Milano, IT: Giuffrè.

Carini, C., Veneziani, M., Bendotti, G., \& Teodori, C. (2014). A possible narrative section harmonisation? The role of the practice statement management commentary. Journal of Modern Accounting and Auditing, 10(1), 1-19.

Chandra, U., Ettredge, M. L., \& Stone, M. S. (2006). Enron-era disclosure of off-balance-sheet entities. Accounting Horizon, 20(3), 231-252. 
Clarkson, P. M., Kao, J. L., \& Richardson, G. D. (1999). Evidence that management discussion and analysis (MD\&A) is a part of a firm's overall disclosure package. Contemporary Accounting Research, 16(1), 111-134.

Cole, C. J., \& Jones, C. L. (2005). Management discussion and analysis: A review and implications for future research. Journal of Accounting Literature, 24, 135-174.

Colucci, E., \& Riccomagno, F. (1999). Il bilancio d'esercizio e il bilancio consolidato. Analisi e soluzioni tecniche. Padova, IT: Cedam.

Consiglio Nazionale dei Dottori Commercialisti e degli Esperti Contabili [CNDCEC]. (2009a). La relazione sulla gestione art. 2428 codice civile. Roma, IT: Consiglio Nazionale dei Dottori Commercialisti e degli Esperti Contabili.

Consiglio Nazionale dei Dottori Commercialisti e degli Esperti Contabili [CNDCEC]. (2009b). La relazione sulla gestione art. 2428 codice civile. Informativa sull'ambiente e sul personale. Roma, IT: Consiglio Nazionale dei Dottori Commercialisti e degli Esperti Contabili.

Core, J. E. (2001). A review of the empirical disclosure literature: Discussion. Journal of Accounting and Economics, 31(1-3), 441-456.

Dainelli, F., Bini, L., \& Giunta, F. (2010). The effectiveness of directives in regulating narrative information: The case of financial key performance indicators. Proceedings from the 5th Workshop on Accounting and Regulation, University of Siena, Siena, Italy.

De Sarno, M. (2007). La relazione sulla gestione. Ruolo informativo e contenuto della stessa. Rivista Italiana di Ragioneria e di Economia Aziendale, 107, 458-466.

Eccles, R. G., \& Lupone, L. (2000). Alla ricerca del valore: Il divario informativo tra società e mercato. Il caso italiano. In L. Guatri, \& R. G. Eccles (Eds.), Informazione e valore. Il caso italiano (pp. 11-32). Milano, IT: Egea.

Eccles, R. G., \& Mavrinac, S. C. (1995). Improving the corporate disclosure process. Sloan Management Review, 36(4), 11-25.

Epstein, M. J., \& Palepu, K. G. (1999). What financial analysts want? Strategic Finance, 80(10), 48-52.

Financial Accounting Standards Board [FASB]. (2001). Improving business reporting: Insights into enhancing voluntary disclosures. Steering Committee Report, Business Reporting Research Project. Norwalk, Connecticut: Financial Accounting Standards Board.

Ginesti, G., Macchioni, R., Sannino, G., \& Spano, M. (2013). The impact of International Accounting Standards Board (IASB)'s guidelines for preparing management commentary (MC): Evidence from Italian listed firms. Journal of Modern Accounting and Auditing, 9(3), 305-320.

Giunta, F., \& Pisani, M. (2005). Il bilancio. Milano, IT: Apogeo.

Greco, G. (2010). Incentives versus regulation: The case of risk reporting. Evidence from Italian listed companies. Proceedings from the 5th Workshop on Accounting and Regulation, University of Siena, Siena, Italy.

Guerini, D., \& Comoli, M. (1988). La relazione degli amministratori. In A. Provasoli (Ed.), La IV e la VII direttiva Cee nel progetto di attuazione. Rivista dei Dottori Commercialisti, Supplement to n. 5.

Healy, P. M., \& Palepu, K. G. (2001). Information asymmetry, corporate disclosure, and the capital markets: A review of the empirical disclosure literature. Journal of Accounting and Economics, 31(1-3), 405-440.

Holder-Webb, L. (2007). The question of disclosure: Providing a tool for evaluating management's discussion and analysis. Advances in Accounting Behavioral Research, 10, 183-223.

Hooks, K. L., \& Moon, J. E. (1993). A classification scheme to examine management discussion and analysis compliance. Accounting Horizons, 7(2), 41-59.

Hope, O. K. (2003). Accounting policy disclosures and analysts' forecasts. Contemporary Accounting Research, 20(2), $295-321$.

International Accounting Standards Board [IASB]. (2010). Management commentary, IFRS practice statement. London, UK: International Accounting Standards Board.

Krippendorf, K. H. (1980). Content analysis: An introduction to its methodology. Beverly Hills, CA: Sage Publications.

Lang, M. H., \& Lundholm, R. J. (1996). Corporate disclosure policy and analyst behavior. The Accounting Review, 71(4), 467-492.

McEwen, R. A., \& Hunton, J. E. (1999). Is analyst forecast accuracy associated with accounting information use? Accounting Horizons, 13(1), 1-16.

Morgan, A. R. (2008). A measure of the precision of forward-looking statements in MD\&As. Retrieved from http://ssrn.com/abstract=1264309

Pisano, S. (2010). La relazione sulla gestione nella comunicazione economico-finanziaria. Teoria, prassi ed evidenze empiriche. Roma, IT: Aracne. 
Pisano, S. (2011). Efficacia della comunicazione economico-finanziaria nella relazione sulla gestione: Un'analisi empirica sulle società quotate italiane. Rivista Italiana di Ragioneria e di Economia Aziendale, 7/8, 417-428.

Previts, G. J., Bricker, R. J., Robinson, T. R., \& Young, S. J. (1994). A content analysis of sell-side financial analyst company reports. Accounting Horizons, 8(2), 55-70.

Quagli, A. (2004). Comunicare il futuro. L'informativa economico-finanziaria di tipo previsionale delle società quotate italiane. Milano, IT: Franco Angeli.

Ramnath, S., Rock, S., \& Shane, P. (2008). The financial analyst forecasting literature: A taxonomy with suggestions for further research. International Journal of Forecasting, 24(1), 34-75.

Rogers, R., \& Grant, J. (1997). Content analysis of information cited in reports of sell-side financial analysts. Journal of Financial Statement Analysis, 3(1), 17-30.

Taffler, R., \& Breton, G. (2001). Accounting information and analyst stock recommendation decisions: A content analysis approach. Accounting and Business Research, 31(2), 91-101. 